\title{
Improving Barley (Hardeum Vulgare L.) Tolerant to Herbicides Injuries Using Two Methods of Safener Application
}

\begin{abstract}
In greenhouse, barley seeds (Hardeum Vulgare L) were treated with 1,8 naphthalic anhydride safener using two methods of application. The first method, seeds were coated with naphthalic anhydride (NA) by tow rates $(0.5$ and $1.0 \% \mathrm{w} / \mathrm{w})$, and the second were soaking for two hours in potassium salt of naphthalic anhydride (KNA) at concentration 20 and $30 \mathrm{mM}$ in K-phosphate buffer to compare the two methods against the toxic effect of postemergence application of imazapic (oraban) and fenoxaprop-ethyl ( furour) compared with fenoxaprop- $p$ ethyl which have safener in its formulation (puma super) at one field and one and half of field rate. All naphthalic anhydride concentration increase glutathione content, glutathione-s-tansferases activities and total chlorophyll determined 30 days after herbicides application. On the other hand all herbicide rates caused significant decrease in all determined parameters. Naphthalic anhydride succeeded to protect barley seedlings from herbicides injuries and the seedlings still alive even with $1.5 \mathrm{~F}$ of field rate. Fenoxaprop- $p$-ethyl ( at the ready made formulation) with one field rate gave an increase in all parameter but the rate of increase were less than that with naphthalic anhydride and its safener failed to protect barley seedlings from its high rate.
\end{abstract}

\section{INTRODUCTION}

Due to the new strategy of the ministry of agriculture to protect the Egyptian environment from agrochemical hazard, many of the potent herbicides had been banded. Weed management in modern agriculture requires efficient weed control technologies that are safe to the crops. Recent efforts are thus aimed at protecting crop from herbicidal injuries by different methods including genetic engineering of herbicide -tolerant crop cultivars as well as herbicide safeners ( El-Deeb, et al. 2002). Herbicide safeners selectively protect crops from herbicide damage without reducing the activity of these herbicides against the target weed species (Davies and Caseley, 1999). Herbicide safeners, also known a antidotes, they are a compounds of diverse chemical families which applied with herbicide to protect crops against their injuries by improving selectivity without reducing the herbicidal potential (Abu-Qare and Duncan, 2002, and Ying, et.al.2008)

The safeners were applied either as mixed formulation with the herbicides or as seed treatment. The most herbicide classes which could be applied with safeners were including: thiocarbamate, chloroacetamide, sulfonylurea, imidazolinones, and aryloxyphenoxy propionates.

Naphthalic anhydride (NA) is considered among the earlier herbicide safeners used in agriculture, NA when used as seed treatments it will be very effective and partially are completely protect cereal against injuries of various herbicides. Naphthalic anhydride is the most versatile safeners, it protect various crops against a wide range of herbicides and it capable of providing safening activity against post-emergence herbicides (Abu-Qare and Duncan, 2002).

Despite extensive research effort the protective mechanism of herbicide safeners is far from being completely understood. Several hypotheses have been advanced for the mechanism (s) of the protective action of herbicide safeners. Safeners protect crop plant from herbicide damage by reducing the ability of herbicide to reach and inhibit their target site. This may be achieved through safeners induce modification of herbicide target enzyme, accelerating herbicide metabolism and detoxification in these crops by oxidation or conjugation (with glucose, glutathione) and thus herbicide became less effective or immobile; increase the response of certain enzyme (e.g. glutathione-S tansferases isozymes) and increase the level of glutathione (Davies and Caseley, 1995 and Hall and Stephenson, 1995).

Conjugation of herbicide via the thiol function of reduced glutathione (GSH) ( $\gamma$ - glutamyl- cysteinylglycine,) is well established as one of the major detoxification and selectivity factor in plants ( Lamourux et. al. 1991). In addition, the tripeptide glutathione may play a key role in the defence of plant against various environmental stress e.g. cold, heat drought, high light, fungal attack and herbicide.

Glutathione S- transferases (GSTs; EC2.5.1.18) are key enzymes catalyzing the detoxification of several herbicides in many plants. These enzymes are a diverse group of cytosolic enzymes found in all eukaryotes which catalyze the conjugation of synthetic electrophilic substrates with the tripeptide glutathione $(\gamma$ - glutamyl cysteinyl- glycine, GSH) (DeRidder, et.al (2002), Dengo and Hatzios (2002), Frova, 2003, Grundy, et. al. 2005 and Buono,et.al.2007). In addition these family of multifunction enzymes in plant and animals that are well

\footnotetext{
${ }^{1}$ Central of Agriculture pesticides Laboratory

Agric. Research center-Sabahia, Alexandria

Received December24, 2008, Accepted December 31, 2008
} 
know for their roles in detoxification of xenobiotics (Riechester et.al.1998) .

Fenoxaprop- $p$ - ethyl is a selective herbicide with contact and systemic action, absorb by leaves and translocated acropetally to the roots, uses as postemergence to control annual and perennial grass weed in broad leaves and (when applied with safeners it control annual and perennial grass weed in wheat, rye and barley, this herbicide is one of the fatty acid synthesis inhibitors due to the inhibition of acetyl CoA carboxylase (ACCase).

Mefenpyr-diethyl (a new foliar acting safener from the chemical group of pyrazolines) is described. Worldwide studies showed that the application as safener for fenoxaprop- $P$-ethyl and iodosulfuron resulted in significant improvements of crop safety in winter wheat, winter rye, triticale, spring wheat, durum wheat and spring barley (Hacker, et.al., 2000). This new safener can protect wheat and barley certain toxic herbicide, fenoxaprop-ethy and its active isomer (Scalla and Roulet, (2002) by increasing GST activity with CDNB as a substrate, and increase GSH and GSH peroxidase. After this safener was uptaken after application and translocated to leaves and roots resulting metabolization and detoxification of the herbicidal ingredients, without affecting metabolism of the herbicides in weeds. Mefenpyr-diethyl is the first foliar acting safener which can be used with herbicides with different modes of action(Hacker, et.al., 2000). Also it could protect wheat and barley from iodosulfuron-methyl sodium (an inhibitor of acetolactate synthase) (Trabold, et.al.2000), pebulate (Baldwin,et.al. 2000)and metsulfuron (King, 2007).

Imazapic is an imidazolinon herbicide which is toxic to cereals, it used as post and pre- emergence to control wide range of annual and perennial weed in non - cropland area . During the 15 years the development of herbicide resistant crop has moved from transgenic resistant crop to glyphosate, and other herbicides to the development of new type of non- transgenic resistant crop to imidazolinon resistant crop (Alister and Kogan, 2005). Imidazolinon herbicide, like imazethapyre, imazapyr and imazapic, are characterized by their herbicidal effect at low doses, a wide spectrum of weed control and high soil persistence (Loux and Reese, 1993). These high soil persistence (may be 90 days or more ) plus the sensitivity of certain crops, like Beta vulgaris, Brassica rapa, Triticum aestivum and Hardeum Vulgare L. However, in many studies barley showed loss in yield with imazapic and imazapyr (Shaw and Wixson 1991) and it reported as a sensitive crop to Imidazolinon herbicides, needing intercropping periods as long as $\mathbf{5 4 0}$ days after application in maize.
The aim of this studies are: a) compare the deference between the two methods of naphthalic anhydride application to the barley seeds against the post - emergence application of fenoxaprop- ethyl (furour), and compare these post- treatment to the ready made formulation from the same herbicide which has safeners (puma super), and b) try to protect barley from the toxic effect of imazapic to extended its used in barley.

\section{MATERIALS AND METHODS}

In greenhouse, barley seeds (Hardeum Vulgare L) were treated with 1,8 naphthalic anhydride using two methods of application: first, seeds were coated with naphthalic anhydride (NA) at 0.5 and $1.0 \% \mathrm{w} / \mathrm{w}$ before planting by dusting pre- weighted seeds in closed container with the appropriate amount of the safeners and shaking to coat the seeds. The second one, seeds were soaked for two hours in potassium salt of naphthalic anhydride (KNA) at concentration (20 and 30 $\mathrm{mM}$ ) prepared in $0.02 \mathrm{M} \mathrm{K}$-phosphate buffer $(\mathrm{pH} 6.5-$ 7.2) (Frear et.al., 1991 and Modified by Houssien and Sabra, 2005). Seeds were planted in $13 \mathrm{~cm}$ diameter plastic pot contains clay soil (41\%clay, $22.2 \%$ silt and $36.1 \%$ sand). Herbicides were applied early post emergence at 3-4 leave stage at one and one and half fold of field rate. Herbicide fenoxaprop-ethyl (2[ 4-(6chloro-2-bezoxazolyl-oxy-phenoxy-] propanoate ) this is (furore $24 \% \mathrm{EC}$, the field rate $0.5 \mathrm{~L}$. / Feddan, the other formulation of this herbicide were (fenoxaprop -p- ethyl) 2[4-(6-chloro-1,3-bezoxazolyl-oxy-phenoxy-] propanoate+ safener (puma super $75 \%$ EW, 0.5L./Feddan) and imazapic, (RS)- 2-(4-isopropyl4-methyl-5-oxo-2-imidazolin-2-yl) -5-methyl nicotinic acid (Oraban $10 \mathrm{~g} / \mathrm{L}$ at $2 \mathrm{~L} /$ Faddan. Barley were left to grow 30 days after treatments. Glutathion -Stransferases activities at shoot and root of barley seedlings, glutathione content and chlorophyll $\mathrm{a}$ and $\mathrm{b}$ were determined at the end of the experiment.

Chlorophyll determination: Chlorophyll $\mathrm{a}, \mathrm{b}$ and total chlorophyll as $\mathrm{mg} / \mathrm{g}$ F.W. were determined in barley leaves according to Grodzinsky and Grodzinsky, (1973), and modified by Sabra (1993)

Glutathione content determination: barley root were extracted with $70 \%$ ethanol at $0^{\circ} \mathrm{C}$, glutathione content (GSH contents as Ug GSH /gm F.W.) were determined spectrophotometry using DTNB (5, 5- di thio bis (2nitrobenzoic acid ) as a substrate in $0.1 \mathrm{ml}$ ethanol at $412 \mathrm{~nm}$ according to Jabalankai and Hatzios (1991).

Glutathione-S-tansferases activities determination: According to Jabalankai and Hatzios (1991) and modified by (Houssien 1999), barley shoot and root were extracted by $0.1 \mathrm{M}$ phosphate buffer ( $\mathrm{PH} 6.8$ ), then specific activity (GST's specific activity as ((Umol 
$\mathrm{CDNB} / \mathrm{min} / \mathrm{mL} / \mathrm{g} \mathrm{F} . \mathrm{W})$ ) of the enzyme were determined by CDNB (1-chloro-2.4-Dinitrobenzen) as a substrate and reduced glutathione at $340 \mathrm{nmm}$. The rate of nonenzyme conjugation was determined.

All data were statistically analysis.

\section{RESULTS AND DISCUSSION}

I- Effect on glutathione content (GSH): both naphthalic anhydrides, (NA and KNA)caused significant increase in glutathione content extracted from root (figure, 1).

NA at $1 \%$ gave the highest increase in glutathione contents by $45.301 \%$ followed by $30 \mathrm{mM}$ KNA by $40.98 \%$ and $20 \mathrm{mM}$ which gave $35.52 \%$ increase. Fenoxaprop- $p$-ethyl+safeners (the ready made formulating puma super), caused $3.77 \%$ increase in glutathione content without significant deference with untreated barley. The cereals respond to safeners is an increase in the total of GSH pool, the significance of this response is unknown but suggested there would be sufficient GSH available for herbicide conjugation in seedlings after safeners treatment, (Hirase and Molin, 2001 and DeRidder et.al., 2002). In addition, naphthalic anhydrides raised GSH content due to the increase of cystein synthase activity in treated seedlings (Mamdouh and Hassan 1998). (Fenoxaprop-ethyl (furour) at field rate and 1.5 fold of field rate, 1.5Fof field rate of imazapic and puma super at $1.5 \mathrm{~F}$ caused death to the plants after 30 days of treatments. All herbicide treatments alone caused the highest decrease in glutathione content which determined in decomposed root without significant deference. Fenoxaprop-ethyl at $1.5 \mathrm{~F}$ gave $87.432 \%$ decrease followed by $1.5 \mathrm{~F}$ imazapic which gave $84.754 \%$ decrease, while, $1 \mathrm{~F}$ fenoxapropethyl and 1F imazapic caused decrease by $76.557 \%$ and $77.158 \%$ respectively. Also, Fenoxaprop-p-ethyl + safeners (puma super) at $1.5 \mathrm{~F}$ field rate caused $81.038 \%$ decreased. Naphthalic anhydride succeeds to protect

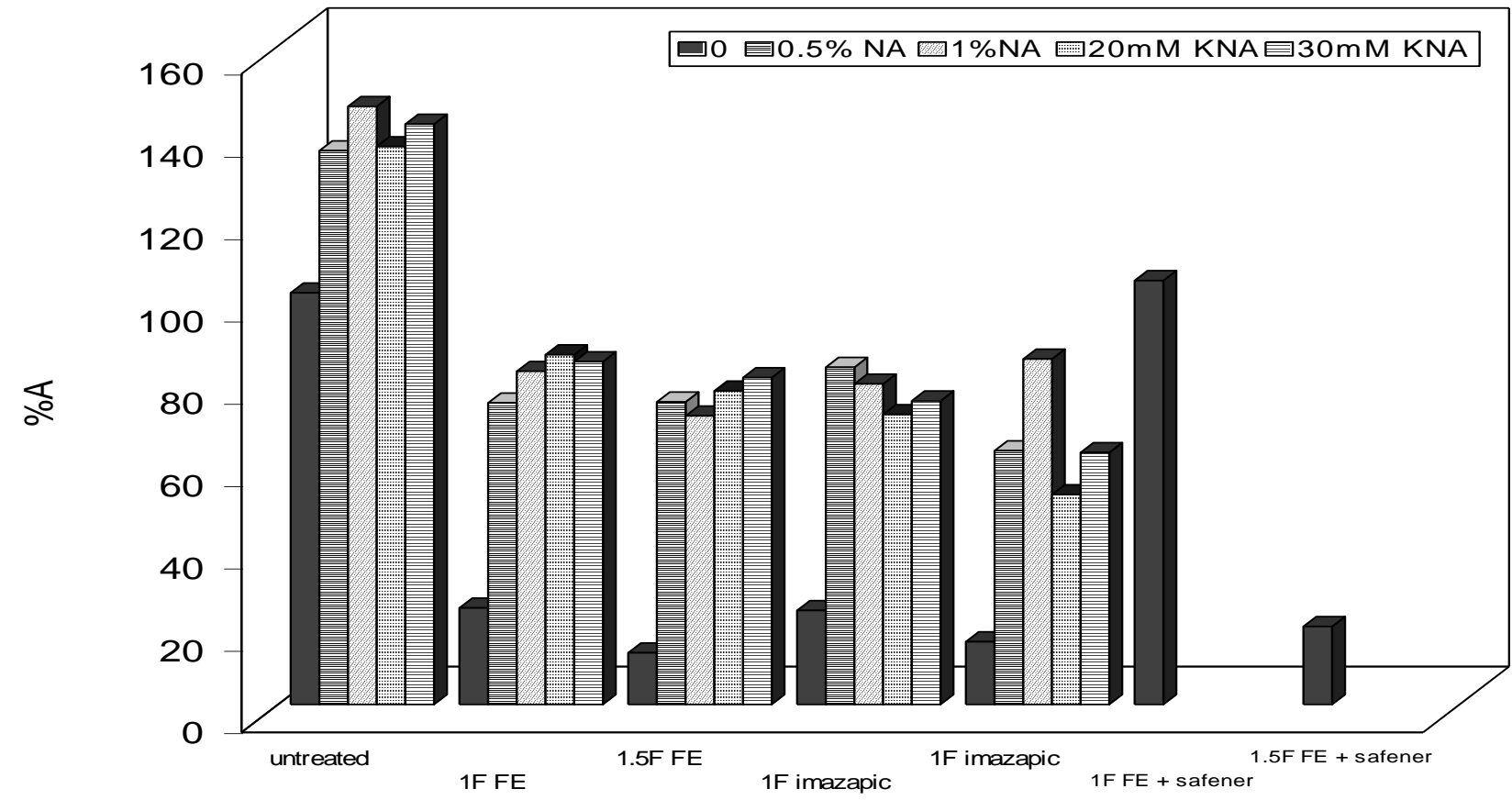

\begin{tabular}{lccccc}
\hline Treatments & $\mathbf{0 . 0}$ & $\mathbf{0 . 5 \%} \mathbf{N A}$ & 1\%NA & 20mM KNA & 30MMKNA \\
\hline 0.0 & 64.211 & 86.383 & 93.298 & 87.018 & 90.526 \\
1F FE & 15.053 & 47.053 & 51.965 & 54.561 & 53.474 \\
1.5F FE & 8.070 & 47.193 & 45.018 & 48.912 & 50.982 \\
1F imazapic & 14.667 & 52.596 & 50.000 & 45.228 & 47.368 \\
1.5F imazapic & 9.789 & 39.579 & 53.895 & 32.737 & 39.298 \\
1F FE + safeners & 66.632 & & & & \\
1.5F FE + safeners & 12.041 & & & \\
\hline LSD $(0.05)=5.036$ & Fenoxaprop-ethyl (FE) & & &
\end{tabular}

Figure1. The effect of fenoxaprop-ethyl, imazapic, NA, KNA, and its combination on glutathione content as \% $\mathrm{A}$ from control 
barley seedlings from the injuries against two herbicide, all pre-treated plant either with NA or KNA still alive until the end of the experiment. There were no significant differences between the tow methods of naphthalic anhydride application at the glutathione content but all these combination reduced the reduction rate of glutathione content, for example, $1 \mathrm{~F}$ fenoxapropethyl gave $76.56 \%$ reduction but when combined with $20 \mathrm{mM} \mathrm{KNA}$, the percentage of reduction became $15.027 \%$.NA at $1 \%$ succeed to protect barley even with $1.5 \mathrm{~F}$ imazapic which gave $16.066 \%$ (imazapic at 1 and $1.5 \mathrm{~F}$ of field rate cause death to the barley plants.

(note: GSH which determined in herbicide treatment alone were in decomposed root which were separate from shoot in the pots).
II- Effect on glutathione-s-transferases activities in barley root:

Figure (2), showed that, both naphthalic anhydride alone (NA and KNA) gave an increase in glutathione -Stansferases activities, $30 \mathrm{mM}$ KNA gave $13.25 \%$ increase, puma super, the formulated herbicide which have safeners gave $17.38 \%$ increase in these enzyme. This illustrated by many workers who mention that. safener increase the activity of one or more of the major herbicide detoxifying enzyme families, including GSTs and cytochrom p450-depend monooxygenases and glucosyltransferases, (Riechester, et.al.,1998). All herbicide treatments alone caused death of barley seedlings after 30 days from treatments, and they gave the highest reduction in the enzyme activities,

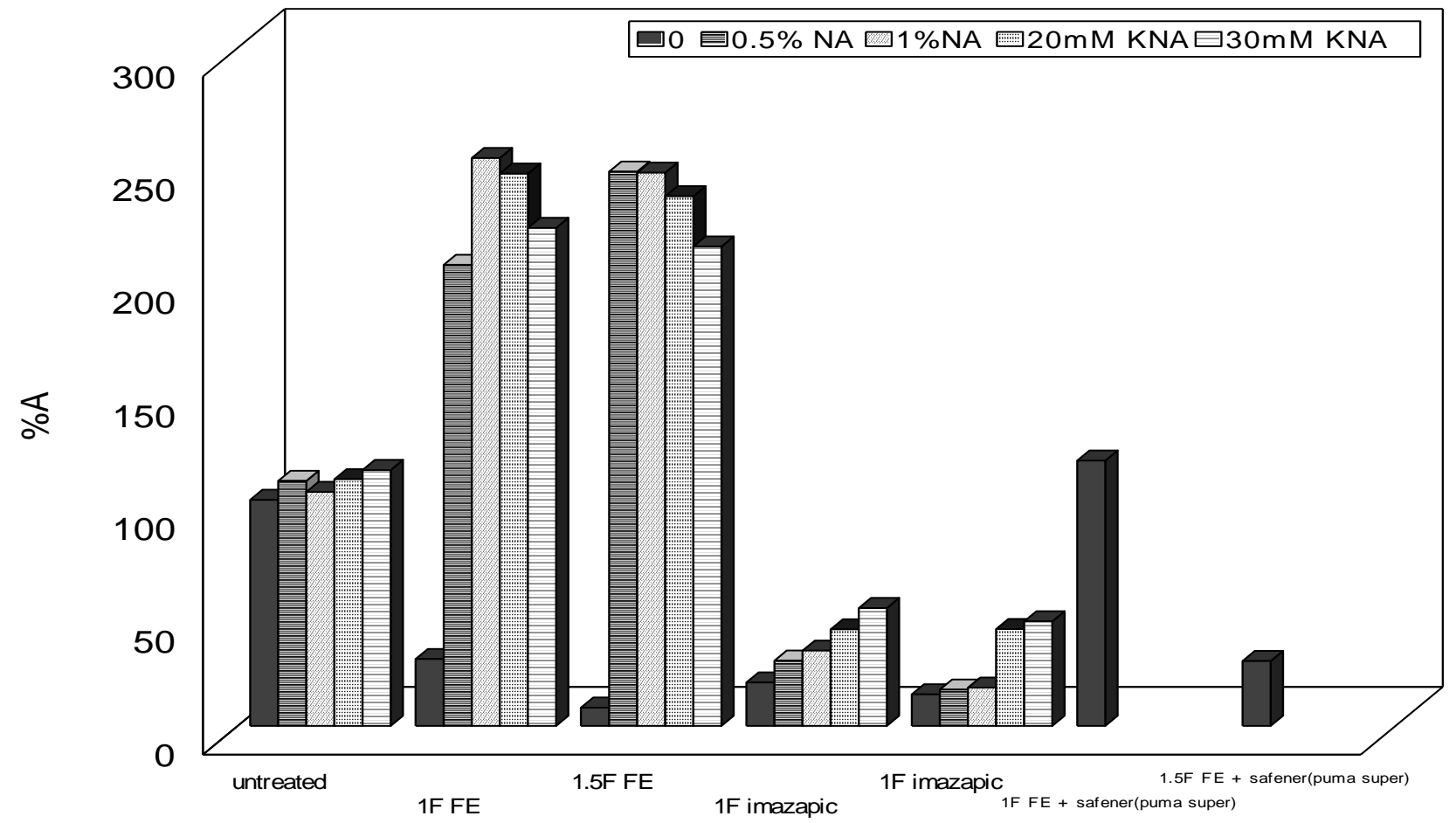

\begin{tabular}{lccccc}
\hline treatments & $\mathbf{0 . 0}$ & $\mathbf{0 . 5 \%} \mathbf{N A}$ & 1\%NA & 20mM KNA & 30MKNA \\
\hline 0.0 & 603.56 & 654.22 & 624.89 & 658.67 & 683.56 \\
1F FE & 178.67 & 1231.11 & 1516.44 & 1474.67 & 1329.78 \\
1.5F FE & 48.89 & 1480 & 1477.33 & 1414.22 & 1280 \\
1F imazapic & 97.78 & 174.22 & 200.89 & 257.78 & 314.67 \\
1.5F imazapic & 84.44 & 96.89 & 102.2 & 258.67 & 379.11 \\
1F FE + safener & 708.44 & & & & \\
1.5F FE + safener & 173.33 & & & &
\end{tabular}

$\operatorname{LSD}(0.05)=38.964$

$\mathrm{FE}=$ fenoxaprop-ethyl

Figure2. The effect of fenoxaprop-ethyl, imazapic, NA, KNA, and its combination on root glutathione-S-tansferases activities as $\% \mathrm{~A}$ from control 
for example, $1.5 \mathrm{~F}$ fenoxaprop-ethyl gave $91.9 \%$ reduction followed by $1.5 \mathrm{~F}$ imazapic which gave $86.01 \%$ and $83.8 \%$ reduction for $1 \mathrm{~F}$ imazapic, respectively, where is Fenoxaprop-p-ethyl + safeners (puma super) at $1.5 \mathrm{~F}$ and $1 \mathrm{~F}$ fenoxaprop-ethyl (furour) gave $71.28 \%$ and $70.4 \%$ reduction, respectively. The highest increase in glutathione $-\mathrm{S}$ - tansferases activities were observed when barley seeds were pre-treated with NA or KNA at all concentration before treated with fenoxaprop-ethy at $1 \mathrm{~F}$ and $1.5 \mathrm{~F}$ of field rate. $1 \% \mathrm{NA}$ $+1 \mathrm{~F}$ fenoxaprop - ethyl gave the highest increase in the activities, it gave $151.2 \%$ increase followed by $0.5 \% \mathrm{NA}$ $+1.5 \mathrm{~F}$ fenoxaprop- ethyl which gave $145.21 \%$ increase, followed by $1 \% \mathrm{NA}+1.5 \mathrm{~F}$ fenoxaprop- ethyl and $20 \mathrm{mM}$ KNA+ $1.5 \mathrm{~F}$ fenoxaprop- ethyl which gave 144.77 and 144.33 respectively. The two methods of naphthalic anhydride application protect barley from death which caused by fenoxaprop-ethyl. Fenoxaprop- ethyl + NA at two concentrations were increased the activities more than the ready made formulation which has safeners inside, NA is better than this safener. These results are agreed with DeRidder, et.al. 2002, so that, treatment of wheat and barley with naphthalic anhydride induce the activity of phi class Ta GST2-3 (enzyme isozymes) which are active in detoxifying fenoxaprop-ethyl). On the other hand, NA also protects plants from imazapic injuries but with decrease in the enzyme activities.

III- Effect on glutathione-s-transferases activities in barley shoot:

Figure (3), showed the activities of glutathione -Stansferases which extracted from barley shoots, these activities were following the same direction of that extracted from roots.

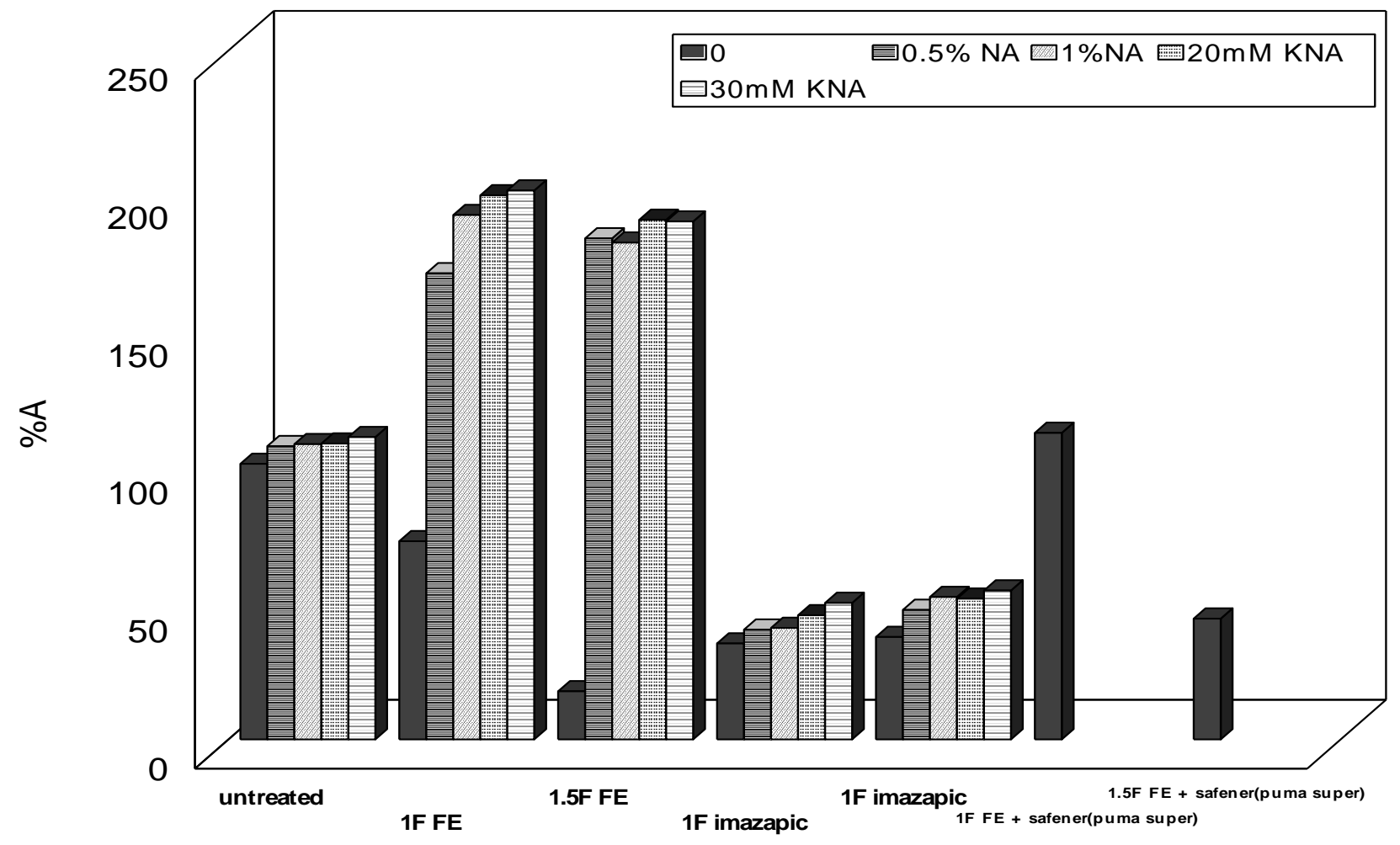

\begin{tabular}{lccccc}
\hline treatments & $\mathbf{0 . 0}$ & $\mathbf{0 . 5 \%} \mathbf{N A}$ & 1\%NA & 20mM KNA & 30mMKNA \\
\hline 0.0 & 870.22 & 926.22 & 932.44 & 934.22 & 954.67 \\
1F FE & 244.44 & 1472 & 1656 & 1718.22 & 1733.33 \\
1.5F FE & 152.89 & 1582.22 & 1568.9 & 1640.80 & 1635.56 \\
1F imazapic & 303.11 & 346.67 & 352 & 392 & 431 \\
1.5F imazapic & 323.56 & 408.89 & 449.78 & 444.44 & 4700.22 \\
1F FE + safener & 968.00 & & & \\
1.5F FE + safener & 433.66 & & & \\
\hline \multicolumn{5}{c}{ Figure 3. The effect of fenoxaprop-ethyl, imazapic, NA, KNA, and its } \\
combination on shoot glutathione -S-tansferases activities as\% A from control
\end{tabular}


All NA and KNA concentration gave small increase in the enzyme activities, where, $30 \mathrm{mM}$ KNA gave $9.7 \%$ whereas $20 \mathrm{mM} \mathrm{KNA}$ and $1 \% \mathrm{NA}$ gave $7.35 \%$ and $7.15 \%$ increase. This enhancement in GST's level were gained before, in cereal crops, safeners enhance the GST's activities (Davies and Casely, 1999 ). The lowest reduction had been obtained from herbicide alone; $1 \mathrm{~F}$ fenoxaprop- ethyl gave $82.43 \%$ reduction followed by $1.5 \mathrm{~F}$ and $1 \mathrm{~F}$ imazapic which gave $62.82 \%$ and $65.17 \%$, reduction respectively without significant differences, compared with the other safeners [ $1.5 \mathrm{~F}$ fenoxaprop- $p$ ethyl + safeners] (puma super) gave 50\% reduction. Naphthalic anhydride protects barley from death even with imazapic which when combined with Naphthalic anhydride caused reduction in the activity but the plant still alive.

VI- Effect on chlorophyll content: All naphthalic anhydride treatments caused increase in total chlorophyll due to its stimulation effect on ch a and ch b , for example $0.5 \%$ and $1 \%$ NA gave $25.401 \%$ and
$26.413 \%$ increase in total chlorophyll due to high increase in cha which was $43.24 \%$ and $43.12 \%$ increase, whereas, only $4.09 \%$ and $6.45 \%$ increase in ch b followed by the ready made formulation of fenoxaprop$p$-ethyl which contain safeners by $13.7 \%$ increase in total chlorophyll (9.6\% increase in ch a and $18.5 \%$ increase in ch $\mathrm{b}$ ). The herbicide treatment alone gave the highest reduction in total chlorophyll, these reduction also due to the highest reduction in ch a and ch $\mathrm{b}$, for example, $1.5 \mathrm{~F}$ imazapic gave $52.1 \%$ reduction in total chlorophyll (51.55\% reduction in ch $\mathrm{b}$ and $52.56 \%$ reduction in ch a). Pre- treatments of barley seeds with naphthalic anhydride succeed to reduce the reduction rate in total chlorophyll, there was no significant deference betweed untreated plant and soaked plant in 20 and $30 \mathrm{mM}$ KNA and plant were posted treatment with $1 \mathrm{~F}$ fenoxapropethyl and imazapic. All barley seedlings treated with fenoxaprop-ethyl at $1.5 \mathrm{~F}$ of field rate when pre-treated either with NA or KNA caused small increase in ch a without significant different compared with untreated plant, (table (1).

Table 1. The effect of fenoxaprop-ethyl, imazapic, NA, KNA, and its combination on chlorophyll (a, b and total) as $\mathrm{mg} / \mathrm{g}$. fresh weight

\begin{tabular}{|c|c|c|c|c|}
\hline \multicolumn{2}{|l|}{ Treatments } & \multirow[b]{2}{*}{ cha } & \multirow[b]{2}{*}{ Chb } & \multirow[b]{2}{*}{$\begin{array}{c}\text { total } \\
\text { chlorophyll }\end{array}$} \\
\hline Herbicide & $\begin{array}{l}\text { naphthalic } \\
\text { anhydride }\end{array}$ & & & \\
\hline \multirow[t]{5}{*}{ Fe } & 0 & 1.38 & 1.16 & 2.536 \\
\hline & $0.5 \% \mathrm{NA}$ & 1.98 & 1.2 & 3.180 \\
\hline & $1 \% \mathrm{NA}$ & 1.98 & 1.23 & 3.206 \\
\hline & $20 \mathrm{mM} \mathrm{KNA}$ & 1.93 & 1.41 & 3.345 \\
\hline & $30 \mathrm{mM} \mathrm{KNA}$ & 1.94 & 1.21 & 3.150 \\
\hline \multirow{5}{*}{ 1F fenoxaprop- ethyl } & 0 & 0.99 & 0.66 & 1.645 \\
\hline & $0.5 \% \mathrm{NA}$ & 1.4 & 0.54 & 1.936 \\
\hline & $1 \% \mathrm{NA}$ & 1.52 & 0.82 & 2.347 \\
\hline & $20 \mathrm{mM} \mathrm{KNA}$ & 1.59 & 0.77 & 2.361 \\
\hline & $30 \mathrm{mM} \mathrm{KNA}$ & 1.64 & 0.91 & 2.555 \\
\hline \multirow{5}{*}{ 1.5F fenoxaprop- ethyl } & 0 & 0.97 & 0.58 & 1.551 \\
\hline & $0.5 \% \mathrm{NA}$ & 1.38 & 0.44 & 1.829 \\
\hline & $1 \% \mathrm{NA}$ & 1.4 & 0.45 & 1.849 \\
\hline & $20 \mathrm{mM} \mathrm{KNA}$ & 1.42 & 0.36 & 1.779 \\
\hline & $30 \mathrm{mM} \mathrm{KNA}$ & 1.52 & 0.53 & 2.052 \\
\hline \multirow{5}{*}{ 1F imazapic } & 0 & 0.78 & 0.63 & 1.418 \\
\hline & $0.5 \% \mathrm{NA}$ & 1.19 & 1.01 & 2.201 \\
\hline & $1 \% \mathrm{NA}$ & 1.14 & 1.17 & 2.309 \\
\hline & 20mM KNA & 1.14 & 1.36 & 2.498 \\
\hline & $30 \mathrm{mM}$ KNA & 1.36 & 1.19 & 2.546 \\
\hline \multirow{5}{*}{ 1.5F imazapic } & 0 & 0.65 & 0.56 & 1.215 \\
\hline & $0.5 \% \mathrm{NA}$ & 1.13 & 1.1 & 2.222 \\
\hline & $1 \% \mathrm{NA}$ & 1.05 & 0.88 & 1.934 \\
\hline & $20 \mathrm{mM} \mathrm{KNA}$ & 1.12 & 0.6 & 1.715 \\
\hline & $30 \mathrm{mM}$ KNA & 1.15 & 0.72 & 1.871 \\
\hline 1F fenoxaprop-p- ethyl + safener & 0 & 1.51 & 1.37 & 2.882 \\
\hline 1.5F fenoxaprop-p- ethyl + safener & 0 & 1 & 0.45 & 1.445 \\
\hline
\end{tabular}

LSD for total $(0.05)=0.103$ 


\section{REFERENCES}

Abu-Qare, A.W. and Duncan, H.J. (2002). Herbicide safeners: Uses, limitation, metabolism and mechanism of action. Chemosphere, 48(9): 965-74.

Alister, C. and Kogan, M. (2005). Efficacy of imidazolinone herbicides applied to imidazolinone resistant maize and their carryover on rotational crops. Crop Protection. 24, 375-79.

Baldwin, A., Francis, D., Rogers, HJ, and Harwood, JL. (2000).The inhibition of fatty acid elongation by pebulate can be effectively counteracted by the safener dichlormid. Biochemical Society Transactions. Portland Press, Colchester, UK: 28: 6, 650-51

Buono ,D.D, Scarponi L.and Espen, L. (2007). Glutathione Stransferases in Festuca arundinacea: Identification,characterization and inducibility by safener benoxacor . Phytochemistry, 68 2614-624

Davies J. and Caseley, J.C. (1995). Mechanism involving the safening of imidazolinone activity in maize by naphthalic anhydride and BAS-145138. Brighton crop protection conference, Weeds 1:275-280.

Davies J. and Caseley, J.C. (1999). Herbicide safeners: a review. Pesticide Science. 55:1043-058.

DeRidder, B.D.; Beussman, D.; Edwared, R. and Goldsbrough,P.B. (2002).Induction of glutathione stansferases in Arabidopsis by herbicide safeners. Plant Physiol., USA:200. 130:3, 1497-1505

Dengo, F. and Hatzios, K.K. (2002). Purification and caracterization of two glutathion $-\mathrm{s}$ transferase isozyme from indica-type rice involved in herbicide detoxification. Pesticide biochemistry \& physiol. 41(1)10-32.

El-Deeb, S.T., Elshazely, A.M., Kassem, F. and Houssien, A.A. (2002). Increasing isoproturon selectivity in grain sorghum by using naphthalic anhydride safener. The First Conf. of the Central Agric. Pesticide. Lab. 3-3 Sep. vol. 2: pp.966-74.

Frear, D.S.; Swanson, H.R. and Thalacker, F.W. (1991). Induced microsomal oxidation of diclofop, triasulfuron, chlorsulfuron and linuron in wheat. Pesticide biochemistry \& physiol. 41:274-87.

Frova, C.( 2003). The plant glutathione transferase gene family: genomic structure, functions, expression and evolution. Physiol. Plant 119, 469-79

Grundy, N.M., Jepson, I, Townson, J. and Edwards, R. (2005). Purification and characterization of a family of glutathione transferases with roles in herbicide detoxification in soybean ( Glycine Max L.); selective enhancement by herbicides and herbicide safeners. Pesticide. 82, 205-19.

Grodzinsky, A.M. and Grodzinsky, D.M. (1973). Short reference in plant physiology. Naukova Domka, Riv., R.U.R. pages 433-34.
Hacker, E., Bieringer, H., Willms, L., Rosch, W., Kocher, H., and Wolf, R.( 2000). Mefenpyr-diethyl: ein Safener fur Fenoxaprop-P-ethyl und Iodosulfuron in Getreide. Zeitschrift fur Pflanzenkrankheiten und Pflanzenschutz. Sonderh. 17, 493-500. 8 ref

Hall, J.C. and Stephenso, G.R. (1995). The basis for the synergizing and safening action of fenoxaprop-ethyl : Brighton Crop Protection Conference weeds.(1): 261-68.

Hirase , K. and Molin, W. (2001). Effect of flurazol and other safeners for chloroacetanilide herbicide on cystein synthase in sorghum shoot. Pesticide bio \& physiol. 71, 116-23.

Houssien, A.A. and Sabra, F.S. (2005). Safening corn seedling in sandy soil from certain herbicides injuries using naphthalic anhydride and its effect on oxidative enzymes. J. Pest Cont. \& Environ. Sci. 13 (2) 25-41.

Houssien, A.A. (1999). Biochemical studies of some herbicides on certain weed and important crops.(safener as a tool for increasing herbicide selectivity to sensitive crops. Ph.D. thesis. Faculty of Agric. Alex. Univ.

Jabalankai, A.A. and Hatzois, K. K.(1991). Role of glutathione and glutathione-s-transferases in the activity of acetochlor in maize and wheat. Pesticide bio \& physiol. 41:221-31.

King, SR, (2007). Effect of mesosulfuron rate and formulation on wild oat (Avena fatua) control and malt barley tolerance. [Journal article] Weed Technology. Weed Science Society of America, Lawrence, USA. 21: 3, 771776

Mamdouh, M. N. and Hassan, N. M. (1998). Efficacy of exogenous GA3 and herbicide safener in protection of zea mays from metolachlor toxicity. Plant Physiol. Biochem. 36(11): 809-15.

Lamoureux, G.L. Shimabukuro, R.H. and Frear, D. S.(1991). Glutathion and glucoside conjugation of herbicide selectivity. In herbicide resistance in weed and crops, J.C. Caseley; G.W. Cussans and R.K. Aikin (Eds), Oxford: pp.227- 61.

Loux, M.and Reese, K.( 1993). Effect of soil type and ${ }_{\mathbf{p}} \mathrm{H}$ on persistence of imazaquin, imazethapyr, and clomazone in soil. Weed Tech. 7, 452-58.

Riechester, D.E.; Kleinhofs, A.; Irzyk, G.P. and Stephen, S.J. (1998). Chromosomal location and expression of a herbicide safener - regulated glutathione - s- transferase gene in Triticum aestivun and linkage relation in Hardeum vulgare. Genome, 41 (3) 368-72.

Sabra, F.S.I. (1993). Studies on chemical weed control on the efficiency of certain herbicides and their side effect on potato plants and soil. Ph.D. thesis. Faculty of Agric. Alex. Univ.

Scalla, R.and Roulet, A (2002). Cloning and characterization of a glutathione $S$-transferase induced by a herbicide safener in barley (Hordeum vulgare). Physiologia Plantarum. Blackwell Publishing, Oxford, UK: 116: 3, 336-44. 
Shaw, D. and Wixson, M. (1991). Postemergence combinations of imazaquin or imazethapyre with AC263,222for weed control in soybean (Glycine max). Weed Sci. 39, 644-49.

Trabold, K. Hacker, E. Hess, M. and Huff, H.P. (2000). Iodosulfuron - a new sulfonylurea herbicide for weed control in cereals. [Conference paper. Journal article].
Zeitschrift fur Pflanzenkrankheiten und Pflanzenschutz.. Sonderh. 17, 701-707. 3 ref.

Ying F.U.; Hong-gang, F.U.; Fei, Y.E, Xiao-tian ,W.' and Jiang, L. (2008). Synthesis, Crystal Structure and Biological Activity of Novel Dichloroacetyl Oxazolidine Herbicide Safeners. Chem. Res. Chinese Universities, 24 (3): 291-94. 


\section{الملخص العربي}

\section{زياده تحمل بادرات الشعير لسميه مبيدات الحشائش بإستخدام طريقتين مختلفتين}

\section{في المعامله بالترياق}

\begin{tabular}{|c|c|}
\hline \multicolumn{2}{|c|}{ أمل أحمد حسين } \\
\hline التجربه بعد 30 يوم مـن المعامله. و لقد أحدثثت تركيزات الترياق & تم عمل تجربـه في الصـوبه الزراعيـه لزياده تحمـل بادرات نبـات \\
\hline بمفردهـــــا زياده معنويـــهـ في محتــوى الجلوتاثيــون و نشـــاط انــزيم & الشعير و المنزرعـه في التربـه الطينيـه لمبيـد الحشـائش فينوكسـابرب- \\
\hline 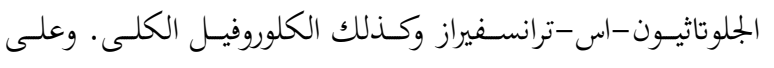 & إيثيل (فيورور) ومبيـد الحشـائش إيمازابيك (أورابان) وذلك بمعامله \\
\hline النقيض من ذلك فقد أحدثت المبيدات بمفردها انخفاض معنوى في & حبـوب الشعير بطريقتين مختلفتـين مسن الترياق نفثاليـك اغيدريـد، \\
\hline كل الصفات المقدره. وقد نجح الترياق في حمايه البادرات من التأثير & الأولى معاملـه الحبـوب الجافـه بالنفثاليـك اهيدريـــ الجــاف بتركيـز \\
\hline السـام الحسادث مـن المبيـدات وكـذلك نجح فن حمايسه البـادرات مـن & (0.5\% و 1\% وزن/وزن)، و الطريقـهـ الثانيـهـ بنقـع الحبـوب فن \\
\hline الموت خاصه مع التركيز 1.5 ضعف الحقلى. مبيد البوما سوبر و & محلول ملح البوتاسيوم من الترياق نفثاليك اخيدريد بتركيز (20،30 \\
\hline الترياق داخل التجهيزه بالتركيز الحقلى أمكنه إحداث زياده في كل & ميكـرو مـول)، وذلـك قبـل الزراعـه و قـــــم تطبيـق المبيـدات بعـد \\
\hline الصفات المقـدره، ولكـن هـذه الزياده بمعـدل أقـل منهـا في حالـه & الأنبثاق في عمر 3-4 ورقات ومقارنه هذه المعاملات بمبيد ( البوما \\
\hline النفثاليك اهيدريـد. فشـل التريق الموجـود في البومـا سوبر في حمايـه & سوبر) والمختوى على المشابه الفعال للفينوكسابرب- إيثيل مضافا \\
\hline بادرات الشعير مـن التـأثير السـام للمبيـــ وذلكك مـن التركيز 1.5 & اليه ترياق داخل التجهيزه, كل المبيدات طبقت بالتركيز الحقلى و \\
\hline ضعف الحقلى بينما نجح ال النفثاليك اهيدريد في ذلك مع هـذا & 1.5 ضعف منه. و قد تم اهاء \\
\hline
\end{tabular}

